\title{
W poszukiwaniu literacko-filozoficznej koinè - o nowoczesnym języku refleksji literaturoznawczej i filozoficznej
}

\author{
...humanistyka wiąże się z postaciami doświadczenia, które pozosta- \\ ją poza sferą nauki: z doświadczeniem filozofii, z doświadczeniem \\ sztuki i z doświadczeniem samych dziejów. Są to wszystko postacie \\ doświadczenia, w których objawia się prawda nieweryfikowalna \\ metodycznymi środkami nauki. (Gadamer 1993: 33-34)
}

roces kształtowania się języka refleksji naukowej, zwłaszcza humanistycznej, jest zjawiskiem niezwykle skomplikowanym. W kręgu moich zainteresowań pozostaje kwestia związku, szczególnego powinowactwa, filozofii i literatury, która w dwudziestowiecznej refleksji naukowej przybrała na sile ${ }^{1}$. Jest to dla mnie problem o tyle ważny, że podczas badań nad literackim zapleczem polskiej filozofii narodowej doby romantyzmu napotykam na szereg trudności metodologicznych, które wiążą się z poszukiwaniem tytułowej literacko-filozoficznej koinè. Zastosowana w tytule formuła koinè jest nawiązaniem do tekstu Gianniego Vattimo Hermeneutyka — nowa koinè, w którym pojawia się teza o tym, iż hermeneutyka stała się mową powszechną współczesnej kultury (Vattimo 1996: 123). Moje badania opierają się na podobnym myśleniu, bowiem uznaję, że tak pojęcia filozoficzne, jak i poetyckie metafory, należą do wspólnoty języka refleksji naukowej (humanistycznej). Podzielam również przekonanie, że rozdzielanie światopoglądu filozoficznego od konwencji stylistycznych nie jest możliwe, a wręcz jest reliktem badań opartych na scjentyzmie, który dziś, jak zauważa Vattimo, „wyczerpał się” i doprowadził do instrumentalizacji testu kultury (Vattimo 1996: 123). Tym mocniej w tym wypadku wybrzmiewają słynne, niemal kanoniczne, rozpoznania

$1 \quad$ Należałoby tu przywołać pracę zbiorową Wypowiedź literacka a wypowiedź filozoficzna pod redakcją Michała Głowińskiego i Janusza Sławińskiego, w której zdefiniowano miejsca spotkań literatury i filozofii, i w której wreszcie dokonano sytuacji, w których to badacz musi zmierzyć się z trudnościami związanymi z poszukiwaniami metodologicznymi badania wypowiedzi literackiej i filozoficznej. 
Jonathana Cullera zawarte w eseju Co to jest literatura i czy pytanie to ma jakiekolwiek znaczenie? (1998). Pytanie „co to jest literatura?”, a także „co sprawia, że przedstawiciele danej społeczności zaliczają tekst w poczet dzieł literackich?” (Culler 1998: 33), są pierwszym krokiem do podjęcia refleksji nad istotą powinowactwa filozofii i literatury. Jestem przekonana, że spuściznę filozoficzną polskich romantyków można badać, wychodząc od takich właśnie wątpliwości. W tych traktatach, prócz oczywistej zawartości ideowej, można odnaleźć określone konwencje stylistyczne, gatunkowe oraz narracyjne, jakby dookreślające, obrazujące sposób myślenia ich autorów o rzeczywistości, Historii i Dziejach. Można także owe dzieła uznać za „opowieść", w pewien sposób narracyjnie uporządkowaną, wysuwającą na pierwszy plan uporządkowanie językowe, „niezwykłe złożenia słów (rollrock)” (Culler 1998: 41). Choć elementy te stanowią fundament badań zarówno tekstów filozoficznych, jak i literackich, w ogromnej większości pozostają zaniedbane z uwagi na fakt, iż historię filozofii traktuje się zwykle jako proces następujących po sobie treści myślowych, nie zaś jako następstwo pewnych typów kształtowania tychże treści (Lîiceanu 2017: 345). Są to te kwestie, które najmocniej zbliżają względem siebie języki nauki/teorii o filozofii i o literaturze. Koresponduje to z sądami Paula Ricoeura na temat zależności między historiografią a fikcyjną opowieścią:

[...] Niezależnie od tego, czy chodzi o stwierdzenie strukturalnej identyczności między historiografią a fikcyjną opowieścią, [...] czy o ukazanie głębokiego pokrewieństwa między wymogiem prawdy obydwóch sposobów narracji, [...] nad wszystkimi innymi założeniami góruje to, że zarówno strukturalna identyczność funkcji narracyjnej, jak i wymóg prawdy każdego narracyjnego dzieła kładzie ostatecznie na szali czasowy charakter ludzkiego doświadczenia. Świat przedstawiony każdego dzieła narracyjnego jest zawsze czasowym światem. Inaczej mówiąc - [...] czas staje się ludzkim czasem w tej mierze, w jakiej zostaje narracyjnie wyartykułowany; natomiast opowieść jest znacząca w takim stopniu, w jakim kreśli zarysy czasowego doświadczenia [...].

(Ricoeur 2008: 17)

Tak rozumiane pokrewieństwo pozornie przeciwstawnych sobie narracji (historiograficznej i fikcyjnej) składnia do tego, by na dzieła filozoficzne spoglądać przez pryzmat kategorii literackich, a także doszukiwać się w nich swoistego uporządkowania charakterystycznego dla literatury. Przywołanej przeze mnie procedury badawczej nie należy jednak rozumieć jako poszukiwania w tekście przedstawienia jakieś miary, proporcji (prawideł), odnajdywania w nim zmysłowo-naocznego poznania piękna przedmiotu badań czy poszukiwania percepcji jego doskonałości (Pakalski 1994: 124). Byłby to bowiem krok ku instrumentalizacji tekstu, ku wpisywaniu go w metodologiczne ramy. Dlatego też hermeneutyka, wywiedziona z dociekań Hansa-Georga Gadamera, Paula Ricoeura, Martina Heideggera czy Georga Steinera, otwiera mnie jako badacza na teksty filozoficzne, powodując, że nie ograniczam się do wyłuskiwania z ich treści literackich chwytów. 


\section{Hermeneutyka jako koinè literatury i filozofii}

Szczególny nacisk na związki literatury i filozofii kładzie hermeneutyka wywiedziona z dociekań wspomnianych Hansa-Georga Gadamera, Paula Ricoeura, Martina Heideggera czy Georga Steinera. Kategorią łączącą to swoiste literacko-filozoficzne spotkanie jest zaś doświadczenie (Czajkowska 2016: 4). Dla współczesnej refleksji naukowej hermeneutyka stała się o tyle ważna, że „w pewnym momencie - jak zauważa Gianni Vattimo - metoda strukturalna stała się karykaturą za sprawą tworzenia — za pośrednictwem opozycji binarnych — sztywnych schematów katalogizująco-opisowych" (Vattimo 1996: 123). Hermeneutyka jawi się zatem jako wspólny język współczesnej kultury, refleksji naukowej — pewnego rodzaju dialog. Bardzo ważny jest dla mnie głos Steinera, którego sposób patrzenia na kulturę można by nazwać mianem „logocentrycznego”. W pracy Poezja myślenia wychodzi bowiem z założenia, iż wszelkie przekazy ludzkie podlegają dynamice i ograniczeniom mowy (Steiner 2016: 9). Odwiecznym pragnieniem całej filozofii (a przynajmniej od czasów Spinozy) jest z kolei ucieczka od zniewolenia języka, „dzięki zmianie języka potocznego w tautologiczną ścisłość, przejrzystość i weryfikowalność” (Steiner 2016: 9). Teza Steinera pokrywa się nieco ze zdaniem Michała Rusinka na temat niebezpieczeństwa, jakie niesie za sobą retoryka:

Niebezpieczeństwo dla rozumu, jakie niesie za sobą retoryka, tkwi jednak nie tylko w zgubnej sile perswazji, lecz także w samej naturze języka, który nie całkiem daje się rozumowi podporządkować. Język czysto referencjalny, logiczny, dosłowny — nie istnieje. Ostatecznie mit takiego języka obalił modernizm, ale już u Kwintyliana znaleźć można tezę, iż „nie ma niczego, co nie byłoby figuralne” - tezę, która jednak zostaje przez niego zawieszona, gdyż nie da się na niej zbudować teorii retoryki, „bo omawiana materia nie da się ująć w przypisy”.

(Rusinek 2003: 9)

Wyraźnym akcentem myśli Steinera jest także przekonanie o metaforyzowaniu zamykającym „sens” przeżyć estetycznych:

W sztukach, w muzyce uchwytujemy rozmaite siły znaczenia, figuracje sensu. Niewyczerpalny sens muzyki, jej niepodatność na przekład ani parafrazę wpływa na filozoficzne scenariusze u Sokratesa, u Nietzschego. Kiedy jednak powołujemy się na „sens” przedstawień estetycznych i form muzycznych, metaforyzujemy, postępujemy na zasadzie mniej lub bardziej jawnej analogii. Zamykamy je w panujących konturach mowy.

(Steiner 2016: 9)

Patrzenie na człowieka jak na „językowe zwierzę" (Gadamer 1979) skłania badacza jednakowoż do refleksji, iż filozofia i literatura wywodzą się z jednego źródła. Zauważa bowiem, że obie te dziedziny mają „identyczne środki performatywne: ciągi słów, odmiany składni, interpunkcję (subtelne środki)” (Steiner 2016: 10). I literatura, i filozofia są zatem działaniami 
językowymi, a retoryczność staje się jednym z podstawowych źródeł zrozumienia istoty łączności tych dyscyplin. Zadania, jakie wyznacza filozofii i literaturze Steiner, przez wzgląd na podjęcie refleksji zgodnie z duchem kognitywistycznym, sprowadzają się zatem, do następujących pytań:

W jakich aspektach filozoficzna propozycja, nawet w nagości logiki Fregego, jest retoryczna? Czy można dany system poznawczy lub epistemologiczny oddzielić od jego konwencji stylistycznych, od sposobów wyrażania dominujących lub kwestionowanych w jego czasie i miejscu? Do jakiego stopnia metafizykę Kartezjusza, Spinozy czy Leibniza warunkuje zespół społecznych i instrumentalnych ideałów później łaciny, warunkują składniki i zasadniczy autorytet częściowo sztucznego już latynizmu w nowożytnej Europie?

(Steiner 2016: 11)

Są to pytania, które prowokują do podjęcia refleksji nad językowym ukształtowaniem każdego tekstu, nie tylko literackiego. Skłaniają także do podjęcia próby odnalezienia w przekazie językowym obrazu sposobu myślenia autora o rzeczywistości, odszyfrowania pewnego kodu kulturowego zawartego właśnie w języku.

\section{Hermeneutyka - Retoryka - Romantyzm}

Próba czytania romantycznych traktatów filozoficznych przez pryzmat interpretacji w duchu hermeneutycznym pozwala mi na zrozumienie ich ładunku znaczeniowego oraz odkrycie sposobu myślenia dziewiętnastowiecznych uczestników kultury o otaczającej ich rzeczywistości. Niejako wiąże się to z rozważaniami Marii Janion nad kulturą, literaturą i filozofią dziewiętnastowieczną, która pokazuje, że dziś mamy do czynienia z nikłą umiejętnością czytania dawnej kultury polskiej (Janion 2006: 7). Autorka proponuje jednakowoż, by zastanowić się nad warunkami, w jakich funkcjonuje współczesna humanistyka (Janion 2006: 7). Okazuje się zatem, że romantycy rościli sobie pretensje do tego, by stworzyć całościową wizję Historii, niejako zaprojektować ją i ogarnąć od chwili stworzenia po jej kres, a interpretacja hermeneutyczna wpisuje się w te założenia. Interpretacje romantyków, kierowane na ruch od źródła do centrum, wpisują się w hermeneutyczny model nie tylko czytania, ale i pojęcia kultury. Zaklęcie w czasie, uwikłanie w Historię, stanowi swoistą metaforę hermeneutyczną, bo jak zauważa Jarosław Ławski:

U romantyków to jednak wieczność kocha się w wytworach czasu i — jednocześnie - wytwory czasu pożądają wieczności i podążają ku niej. Ta jednoczesność w jakimś sensie jest właśnie romantycznością. Zestrojeniem, synergią, spotkaniem ruchu stąd wiodącego tam - i otwarciem owego tam na to, co jest 
Słowa są zatem nie tylko elementami systemowymi, ale stanowią także pewnego rodzaju „nośnik komunikacyjny”. Dzieło literackie składające się ze znaków jest nastawione na wywołanie szczególnego rodzaju współodczuwania. Badanie retoryki w sposób nie do końca oczywisty, wpisuje się w ten model interpretacyjny. W powszechnym przekonaniu sprowadza się ono do analizowania językowych i literackich, czysto teoretycznych, systemowych wykładników. Gdy jednak weźmie się pod uwagę fakt, iż retoryka słowa pojmuje jako elementy wywołujące określone skutki w ludzkich umysłach, okazuje się, że jedynie traktowanie komparatystyki i retoryczności jako odwiecznego sposobu myślenia ludzi jest słuszną drogą interpretacyjną i analityczną. Retoryka, rozumiana jako sztuka ewokująca różnego rodzaju emocje poprzez językowe środki reprezentacji, wpisuje się tym samym w hermeneutyczny model lektury. Łączy w sobie bowiem dwa systemy poznawcze: obiektywistyczny i konstruktywistyczny, o których pisze między innymi Adam Regiewicz:

[...] Ten pierwszy [obiektywistyczny - M.U.] zakłada, że istnieje pewna wiedza, zespół danych, które za pomocą odpowiednich metod można przełożyć na rzeczywistość i odwrotnie. Wiążą się z tym także postawy epistemologiczna i esencjonalistyczna, które zakładają istnienie pewnego obiektywnego sensu, do którego można dotrzeć. Ten drugi model, nazywany konstruktywistycznym [...], stwierdza, że rzeczywistość nie istnieje obiektywnie, a jest jedynie zbiorem praktyk kulturowych czy społecznych — zależy zatem od kontekstu [...].

(Regiewicz 2016: 12)

Wobec tego przy badaniu retoryczności tekstów filozoficznych uwzględniam jednocześnie nurt hermeneutyczny (próbuję odnaleźć sens, który determinuje „mój” odbiór tekstu) oraz żywię przekonanie o istnieniu owego zespołu danych teoretycznych, które odsłaniają to, co „ukryte pod językiem, pod znaczeniami” (Regiewicz 2016: 14). Poszukiwanie dziedzictwa, zakorzenienia w historii (ale nie historii rozumianej jako rekonstrukcja zdarzeń) w połączeniu z filologicznym podejściem do tekstu pokazuje, że ma on przez figury retoryczne „zdolność do organizowania myślenia i rozumienia świata we właściwy sobie sposób” (Szczęsna 2010: 109). Mówi o tym Katarzyna Wądolny-Tatar w kontekście badań nad młodopolską metaforyką oniryczną:

Refleksja naukowa ma zawsze charakter epistemologiczny, jest rodzajem poznawczej penetracji jakiejś rzeczywistości. W wypadku badanych utworów lirycznych stanowi także próbę odpowiedzi na pytania: co metafora oniryczna może [jeszcze] powiedzieć o epoce, w jakiej powstały te teksty, jaki obraz świata wyłania się z młodopolskich tekstów. Ich autorzy zamknęli w metaforach własny sposób odczuwania świata, czytelnik-badacz — obcując z metaforami - rozpoznaje świat pośrednio, poprzez środek wyrazu. 
Chodzi zatem o zakorzenienia kultury, które jak sądzi Wrzosek, „decydują, jak strukturalizujemy, jak kategoryzujemy i metaforyzujemy świat, decydują, jaki powstaje w naszym myśleniu i jaki przekazujemy innym w procesie komunikowania jego obraz" (1995: 7). Oznacza to, że jedynym sposobem wyrażenia siebie i świata jest metaforyzowanie. Pisze także o tym Michał Paweł Markowski:

Mnożę metafory, bo nie ma innego sposobu na uchwycenie tego, co najważniejsze, klecę konteksty, bo nic nie istnieje samo w sobie, tłumaczę z różnych języków i oddaję głos innym tłumaczom, skaczę z dyskursu w dyskurs, bo nie ma innej rady, stawiam żagle na tysiąc sposobów, że nie pochłonął mnie ocean nudy.

(Markowski 2015: 5)

Metafory w tym wypadku nie są traktowane jako figury retoryczne, oddziałujące środki wypowiedzi czy narzędzia ataków politycznych, ale jako „pozostatości, rudymenty na drodze od mitu do logosu" (Blumenberg 2017: 11). Hermeneutyka zajmuje się bowiem nie tyle problematycznością tekstu, co wpływem (Wirkunsgeschichte), jaki wywiera on na odbiorców każdej kolejnej epoki. Figury retoryczne, będące swoistymi elementami systemu języka nauki o literaturze, stanowią także narzędzie opisu i wyjaśniania rzeczywistości. Taki stan Regiewicz nazywa obrazem „miękkiej rzeczywistości”, którą można poddawać pojęciowemu uporządkowaniu i który uświadamia przewagę retoryczności nad ontologią (Regiewicz 2016: 16-17). Badanie retoryczności wymaga zatem zarówno dużych umiejętności analitycznych, jak i interpretacyjnych. Gadamer zresztą argumentuje to w taki oto sposób:

Uważam za całkowicie bezzasadne przypisywanie — jak Habermas — retoryce charakteru przymusu, z którego musimy się wyzwolić na rzecz nieskrępowanej racjonalnej rozmowy. [...] Jakkolwiek praktyka społeczna - także praktyka rewolucyjna - jest nie do pomyślenia bez retoryki. [...] Upraszcza się sens retoryki, widząc w niej tylko technikę, wręcz narzędzie manipulacji społeczeństwem. W rzeczywistości stanowi ona istotną stronę rozumnego zachowania. Już Arystoteles nie nazywa retoryki techne, lecz dynamis, do tego stopnia wchodzi ona w skład ogólnego przeznaczenia człowieka: bycia istotą rozumną.

(Gadamer 2004: 743)

Retoryka nie jest zatem tylko sztuką pięknego mówienia, narzędziem manipulacji i wpływu, lecz także zdolnością człowieka rozumnego. Jednocześnie w ujęciu hermeneutycznym włada (manipuluje) odbiorcą tekstu i dlatego „sztuka interpretacji obficie czerpie środki z retoryki” (Gadamer, cyt. za: Carrilho, Meyer i Benoit 2010: 273). Zakładam zatem, że pytania rodzące się podczas lektury tekstu różnią się w zależności od epoki (nie można uniknąć postawy współczesnego uczestnika kultury). W dziele literackim tkwi zaś zdolność do produkowania nowych wątpliwości. Zdaje się bowiem, że pytania wcześniej niezadawane wraz z doświadczeniem innego czasu ujawniają się i że dzieło literackie jakby na nowo zyskuje żywotność 
dzięki nim. Wraz z doświadczeniem „historii” nieznane „wątpliwości” i problemy wystawiają się na widok.

Próby interpretacyjne podejmowane w takim duchu wpisują się w holistyczny obraz rzeczywistości, wynikający z przekonania o tym, iż patrzenie z perspektywy współczesnego uczestnika kultury jest nieuniknione. Dzieło traktowane jest w tym wypadku jako pewnego rodzaj komunikat z przeszłości, zawierający określoną prawdę. Za Katarzyną Rosner można powiedzieć, iż „myślenie historyczne w rozumieniu hermeneutyki nie ma na celu rekonstrukcji tego, co minione, lecz jest zawsze ustaleniem związku między ideami przeszłości i teraźniejszością, tj. naszym własnym sposobem myślenia” (1992: 245). Poniekąd koresponduje to z sądami wygłaszanymi przez Gadamera, który zauważa, że „pojęcie dzieła wskazuje na sferę wspólnego użytkowania i tym samym wspólnego rozumienia, na komunikowanie się w obrębie zrozumiałości” (1993). Katarzyna Wądolny-Tatar z kolei uznaje, iż „obiektywizacja jest możliwa tylko z oddalenia czasowego. Wpływa on [czas - przyp. M.U.] na stan obcowania czytelnika i badacza, nie jest to jednak stan całkowitej alienacji, znosi ją bowiem kontakt z literaturą, zrozumienie w słowie pisanym" (Wądolny-Tatar 2006: 10). Hermeneutyczny model czytania tekstu sytuacje badacza określa, idąc za Mieczysławem Dąbrowskim, „w kontekście naszej kultury, wiedzy, wrażliwości, czasu historycznego, bagażu doświadczeń itp.” (Dąbrowski 2005: 22).

W procesie tworzenia romantycznej świadomości narodowej zwróconej ku osadzeniu Słowian w Dziejach oraz interpretacji literatury jako źródła dla myśli (będących przedmiotem moich badań) istotna wydaje się także kwestia podejścia polskich heglistów do hermeneutyki. Przedstawiciele tego nurtu podejmowali badania nad walorami językowymi swoich traktatów i umieszczali je w refleksji hermeneutycznej. Pierwszym tego typu dziełem była rozprawa Józefa Kremera Rys filozoficzny umiejętności. Autor dokonał w niej nie tylko encyklopedycznego przedstawienia filozofii Hegla, ale także wskazał reguły przenoszenia filozofii mistrza na grunt języka polskiego (Stachurski 1998: 15). Rozprawa Kremera, zawierająca w swym ujęciu przełożony na język polski niemal cały zasób słowny, treściowy i pojęciowy filozofii autora Fenomenologii ducha, stała się źródłem analogicznych poszukiwań filozoficznych dla innych polskich heglistów (Stachurski 1998: 18). Także i na Libelta (którym zajmuję się w sposób szczególny) dzieło to wywarło silny wpływ, a tytuł jego pierwszej rozprawy Filologia, filozofia i matematyka uważane jako zasadnicze umiejętności nowego wychowania (1838) - odzwierciedla dość wyraźnie podejmowaną przezeń refleksję nad istotą języka filozofii. Hermeneutyka dla Libelta jest o tyle ważna, że on sam, udoskonalając propozycję Kremera, traktował ją nie tylko jako refleksję towarzyszącą, ale także jako problem warunkujący myślenie (Libelt 1971: 225). Wpisuje się tym samym w nowoczesne rozumienie tej dyscypliny, bo jak sam zauważa, polega ona na tym, iż „dzieło każde od najdrobniejszych jego części aż do całości ze wszystkich stron ogląda i pojmuje, prowadzi do najdokładniejszego jego zrozumienia [...]" (Libelt 1971: 226). Hermeneutyka jawi się jako dyscyplina fundamentalna zarówno dla nauk filologicznych, jak i matematycznych. Stanowi także ważny element na drodze do odszyfrowania językowego zapisu, bo zastosowanie jej jako narzędzia interpretacyjnego prowadzi do zrozumienia mechanicznych środków języka, odsłonięcia tajemnicy ich znaczeniowej siły. Pozwala to z kolei na traktowanie każdego tekstu jako całości, jedności treści i formy. Filozof traktuje zresztą słowa jako środki posiadające ładunek umysłowy, czego wyraz daje w wymienianej już rozprawie Filologia, fllozofia i matematyka uważane jako zasadnicze umiejętności naukowego wychowania: 
Wyrazy języka są to mechaniczne środki, w których utajona jest siła umysłowa; im stosowniej, im z lepszym doborem urobione i użyte, tym wyżej unoszą umysł, tym potężniejszy dają mu popęd, tym więcej porywają zdumienie nad tą niewidzialną siłą. Geniusze tylko tą siłą władają [...].

(Libelt 1971: 224)

Libelt, podobnie zresztą jak i inni polscy hegliści, jawi się jednak nie tylko jako znamienity teoretyk związków filozofii i literatury, autor rozdziału Mistycyzm jako przejście do filozofii stowiańskiej, wchodzącego w skład Samowtadztwa rozumu, systematyzującego zagadnienie polskiej poezji wieszczej, ale także jako pisarz świadomie wykorzystujący język. Świadczą o tym licznie zestawiane przez niego teksty literackie różnych epok (na przykład zestawienie cytatu z Pism filozoficznych Cycerona, „O, ojcze, o, ojczyzno, domu Priama!” [O pater, o patria, o Priami domus] (1961: 613) z fragmentem wiersza Hymn do mitości ojczyzny Ignacego Krasickiego „Słodka miłości kochanej Ojczyzny!” [sic!], które są komparatystycznym zestawieniem świata starożytnego i świata nowożytnego, formą wpisania Słowian w ciągłość dziejową ${ }^{2}$; czy liczne odwołania do dzieł literackich, jakby dookreślanie ich treścią stawianych tez i rozpoznań filozoficznych). „Literackość” Libelta objawia się także w świadomym jego nawiązywaniu do estetyki dzieł literackich doby romantyzmu. To już nie tylko zestawianie ze sobą Południa i Północy na wzór poetyckiego obrazu dzikich stepów Ukrainy przeciwstawionych cyprysowemu gajowi, ale także wykorzystanie na przykład estetyki wzniosłości. W jego twórczości filozoficznej można bowiem odnaleźć wszystkie te obrazy, które w poezji wieszczej także są chętnie wykorzystywane, a które powiązane są z zapleczem emocjonalnym języka. Odnajdziemy więc u autora Dziewicy Orleańskiej gwiazdy, meteory, błyskawice, wulkany czy dzikie orkany i szalejące burze świadczące o tym, że kosmos, który opisuje, znajduje się u swych granic, i przygotowuje się na wielką przemianę. W tych traktatach znajdziemy także szereg metafor, które obrazują stan świadomości nie tylko Libelta, ale także całej dziewiętnastowiecznej formacji myślowej. Mam tu na myśli na przykład metaforę terra incognita (Blumenberg 2017), której zastosowanie świadczy o pojmowaniu przez Libelta zadania, jakie sobie wyznacza podczas próby tworzenia polskiej filozofii narodowej. Kiedy pisze: „Torujemy tu sami drogę i może, jak Kolumb, nie natrafimy na sam ląd stały, ale na pierwsze jego wyspy, które byśmy także chcieli nazwać San Salwador" (Libelt 1875: 7), wyraźnie wskazuje, że porusza się po nieznanych dlań lądach. Jest to jednak procedura, która dla potomnych stanie się pewnego rodzaju drogowskazem, punktem zaczepienia.

\section{Podsumowanie}

Rozumienie związków literatury i filozofii zaprezentowane przeze mnie w niniejszym eseju jest próbą odnalezienia metodologicznej drogi do odczytania tekstów filozoficznych, które moim zdaniem zawierają repertuar środków systemowych charakterystycznych zarówno dla literatury, jak i filozofii, oraz posiadają pewien ładunek znaczeniowy, możliwy do odczytania tylko dzięki próbom rozszyfrowania specyficznego kodu kulturowego. Retoryczność, pojmowana w duchu hermeneutycznym, staje się przy tym punktem wspólnym dla filozofii i litera-

2 Szczegółowo opisuję to zagadnienie w artykule: Romantyczna integralność kultury w myśli filozoficznej Karola Libelta (z perspektywy badań literaturoznawczych), Magazyn antropologiczno-społeczno-kulturowy „Maska” 2018, nr 38, s. 201-214. 
tury. Rozumiem ją bowiem przede wszystkim jako wyraz sposobu myślenia o rzeczywistości, jako swoisty rodzaj programu kulturowego i filozoficznego epoki. Napięcie powstałe między tymi dyscyplinami zmusza zatem do zderzenia ze sobą idei filozoficznych i refleksji nad językiem wypowiedzi filozoficznej. Poszukiwania metodologiczne stają się przy tym próbą odpowiedzi na pytanie o to, w jaki sposób mówić o romantycznym dyskursie filozoficznym (zespole światopoglądów wzajemnie się uzupełniających, określonym systemie historiozoficznym i kulturowym itp.). Ich wyrazem jest droga, jaką współcześni badacze wytyczyli w swoich badaniach nad przenikalnością i rozdzielnością dyskursu filozoficznego i literackiego, a także niewątpliwą życiodajnością, jaka rodzi się w napięciu między nimi. Analiza języka traktatów Libelta, ich poetyki, potwierdza tylko, że oddzielanie światopoglądu od konwencji stylistycznych, gatunkowych czy narracyjnych, jest oparte na zgubnym scjentyzmie, a sami filozofowie (zwłaszcza romantyczni) nie uciekają od literatury, uznając ją wręcz za źródło wszelkiej myśli.

MARTYNA UJMA

(iD) https://orcid.org/0000-0002-7896-9941

Uniwersytet Humanistyczno-Przyrodniczy im. Jana Dlugosza w Częstochowie

Wydział Filologiczno-Historyczny (Instytut Filologii Polskiej)

Kontakt: martyna-lenart21@wp.pl

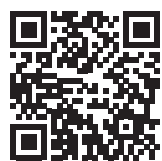




\section{Bibliografia}

Blumenberg Hans (2017), Paradygmaty dla metaforologii, tłum. B. Baran, Aletheia, Warszawa. Carrilho Manuel Maria, Meyer Michel, Benoit Timmermans (2010), Historia retoryki od Greków do dziś, tłum. Z. Baran, Aletheia, Warszawa.

Culler Jonathan (1998), Co to jest literatura i czy pytanie to ma jakiekolwiek znaczenie? [w:] tegoż, Teoria literatury, tłum. M. Bassaj, Prószyński i S-ka, Warszawa.

Cyceron (1961), Pisma filozoficzne, t. III, tłum. W. Korantowski, J. Śmigaj, Z. Cierniakowa, komentarz i posłowie K. Leśniak, Warszawa.

Czajkowska Agnieszka (2016), Filozof na prowincji w utworach pisarzy XIX wieku (wybrane zagadnienia), „Wiek XIX. Rocznik Towarzystwa Literackiego im. Adama Mickiewicza”, rok IX.

Dąbrowski Mieczysław (2005), Projekt krytyki etycznej. Studia i szkice literackie, Universitas, Kraków.

Gadamer Hans-Georg (1979), Cztowiek i jezzy [w:] tegoż, Rozum, stowo, dzieje. Szkice wybrane, wybrał, oprac. i wstępem opatrzył K. Michalski, tłum. M. Łukasiewicz, K. Michalski, PIW, Warszawa.

- (1993), Aktualność piękna. Sztuka jako gra, symbol, święto, tłum. K. Krzemieniowa, Oficyna Naukowa, Warszawa.

- (2004), Prawda i metoda. Zarys hermeneutyki filozoficznej, tłum. B. Baran, Inter-Esse, Warszawa.

Janion Maria (2006), Niesamowita Stowiańszczyzna. Fantazmaty literatury, Wydawnictwo Literackie, Kraków.

Libelt Karol (1875), Filozofia i krytyka, t. 4: Estetyka czyli umnictwo piękne. Część ogólna, Poznań.

- (1971), Filologia, filozofia i matematyka uważane jako zasadnicze umiejętności naukowego wychowania [w:] tegoż, Pisma o oświacie i wychowaniu, wybrał J. Szewczyk, PIW, Warszawa.

Lîiceanu Gabriel (2017), Gatunki filozoficzne [Philosophical genres], „Przestrzenie Teorii”, nr 27.

Ławski Jarosław (2010), Mickiewicz - mit - historia: studia, Trans Humana Wydawnictwo Uniwersyteckie, Białystok.

Markowski Michał Paweł (2015), Kiwka, Austeria, Kraków.

Pakalski Dariusz (1994), Problem celowości piękna w estetyce Kanta, „Sztuka i Filozofia”, nr 8.

Regiewicz Adam (2016), Kerygmatyczne figury interpretacji, Universitas, Kraków.

Ricoeur Paul (2008), W kręgu opowieści czasowych [w:] tegoż, Czas i opowieść, t. 1: Intryga i historyczna opowieść, tłum. M. Frankiewicz, Wydawnictwo UJ, Kraków.

Rosner Katarzyna (1992), Hermeneutyczny model obcowania z tekstem literackim [w:] red. Sawicki S., Tyszczyk A., Problematyka aksjologiczna w nauce o literaturze, Wydawnictwo KUL, Lublin.

Rusinek Michał (2003), Między retoryka a retorycznością, Universitas, Kraków.

Stachurski Lech (1998), Heglizm polski. Elementy strukturalne, Oficyna Wydawnicza Politechniki Warszawskiej, Warszawa.

Steiner George (2016), Poezja myślenia, tłum. B. Baran, Aletheia, Warszawa.

Szczęsna Ewa (2010), Ontologia i epistemologia porównania [w:] red. Szczęsna E., Kasperski E., Komparatystyka dzisiaj. Problemy teoretyczne, Universitas, Kraków.

Ujma Martyna (2018), Romantyczna integralność kultury w myśli filozoficznej Karola Libelta ( $z$ perspektywy badań literaturoznawczych), Magazyn antropologiczno-społeczno-kulturowy „Maska”, nr 38, s. 201-214. 
Vattimo Gianni (1996), Hermeneutyka - nowa koinè, przeł. B. Stelmaszczyk, „Teksty Drugie”, nr 1 .

Wądolny-Tatar Katarzyna (2006), Metaforyka oniryczna w liryce Mtodej Polski, Wydawnictwo Naukowe Akademii Pedagogicznej w Krakowie, Kraków.

Wrzosek Wojciech (1995), Historia - kultura - metafora. Powstanie nieklasycznej historiografii, Leopoldinum, Wrocław.



